\title{
Functional and Structural Changes of the Retinal Nerve Fiber Layer and Ganglion Cell Complex in Heavy Smokers
}

This article was published in the following Dove Press journal:

Clinical Ophthalmology

\author{
Marwa Abdelshafy \\ Ahmed Abdelshafy \\ Ophthalmology Department, Benha \\ University, Benha, Egypt
}

Correspondence: Marwa Abdelshafy Faculty of Medicine, Ophthalmology Department, Benha University, I El Amirafawzya Street, Benha, Qalubiya Governorate, Benha 135I2, Egypt Email Drmarwatabl2012@gmail.com
Purpose: To assess the functional and structural changes in the retinal nerve fiber layer (RNFL) and the ganglion cell complex (GCC) in heavy smokers using pattern electroretinogram (PERG), photopic negative response(PhNR) and spectral domain optical coherence tomography (SD-OCT).

Patients and Methods: Sixty eyes of 30 heavy smokers (at least 15 cigarettes/day for 10 years) (study group) and 60 eyes of 30 age and gender-matched healthy non-smoker subjects (control group) were included. After full ophthalmologic examination (PERG), (PhNR) using RETI-port/scan 21 (Roland Consult, Brandenburg, Germany) and (SD-OCT using Topcon 3D OCT model 2000 FA version.8.30) were tested for all participants. Statistical analysis was performed to compare GCC, RNFL thicknesses, PERG and phNR values between groups.

Results: The mean age was $36.67 \pm 4.13$ years in the study group and $36.0 \pm 4.76$ years in the control group. There were no statistical significant differences between the two groups regarding intraocular pressure $(p=0.43)$, axial length $(p=0.37)$, and central corneal thickness $(p=0.86)$. There were significant differences of GCC thickness values between the study group $(88.4 \pm 6.6 \mu \mathrm{m})$ and control group $(94.83 \pm 5.25 \mu \mathrm{m})(\mathrm{p}<0.001)$. The mean RNFL values of study and control groups were $97.87 \pm 5.88$ and $106.43 \pm 6.59 \mu \mathrm{m}$, respectively $(\mathrm{p}<0.001)$. In the study group the superior and inferior quadrants of RNFL were significantly thinner, but there were no significant differences between the two groups in nasal and temporal quadrants. There were no significant differences of PERG-P50 amplitude ( $\mathrm{p}=0.49)$ and latency $(\mathrm{p}=0.71)$; however, PERG-N95 amplitude and latency showed significant differences between the two groups $(\mathrm{p}<0.001)$. There were significant differences of phNR amplitude and latency between the two groups $(\mathrm{p}<0.001)$. Multiple regression analyses demonstrated that the PhNR, PERG amplitude and latency are the most important determinants for both RNFL and GCC thicknesses.

Conclusion: In heavy smokers RNFL thickness was decreased, the PhNR, PERG-N95 amplitudes were diminished and the implicit times were prolonged compared to non-smokers. PhNR and PERG reflect both dysfunction and loss of ganglion cells and their axons.

Keywords: GCL, nerve fiber layer, optical coherence tomography, pattern electroretinogram, photopic negative response

\section{Introduction}

The World Health Organization (WHO) estimated that tobacco could kill around six million individuals each year, including five million deaths due to direct tobacco use and about 600,000 deaths of non-smokers being vulnerable to passive smoking. The increased number of cigarettes smoked per day and the duration of smoking are emphatically affiliated to high mortality and morbidity rate. ${ }^{1}$ 
Tobacco smoke consists of more than 4000 synthetic compounds that are harmful to the cardiovascular and respiratory systems. Smoking increases the risk of atherosclerotic and thrombo-embolic complications. ${ }^{2}$ It also increases the risk of developing many visual pathologies such as glaucoma, cataract, diabetic retinopathy, hypertensive retinopathy, thyroid orbitopathy, age-related macular degeneration (ARMD), ischemic optic neuropathy, keratoconjunctivitis sicca and retinal vein occlusion. ${ }^{3,4}$

Heavy smoking and excessive nicotine result in direct neurotoxic impact on the optic nerve. This neurotoxic effect may be accompanied by vasoconstriction and reduction of blood flow that lead to ganglion cell and retinal nerve fiber layer (RNFL) loss. ${ }^{5}$ Previous research reported diminished retinal sensitivity and peripheral scotoma in the visual fields of heavy smokers. ${ }^{6}$

Spectral domain-optical coherence tomography (SDOCT) with advanced software (e.g., enhanced depth imaging) generates high resolution cross-sectional images and provides a quantitative measurement of the peripapillary retinal nerve fiber layer (cpRNFL) and ganglion cell-inner plexiform layer complex (GC-IPL). ${ }^{7}$ The pattern electroretinogram (PERG) is an objective test that provides assessment of the central $/ \mathrm{macu}-$ lar retinal functions. ${ }^{8}$ The origins of N95 wave from ganglion cell allow electrophysiological assessment of their function in primary and secondary optic nerve dysfunctions, where particular loss of N95 component can be noticed. ${ }^{9}$

The photopic negative response (PhNR) is the negative potential that occurs after the b-wave of the ERG. It originates from the retinal ganglion cells (RGC) and their axons so it represents the ganglion cell and inner retinal cell function. ${ }^{10}$ It can be decreased in diseases that influence the inner retina, including glaucoma and different types of optic neuropathy. ${ }^{11}$ Previous studies have reported a correlation between the amplitudes and latency of the PhNR with the mean RNFL thickness. This indicates that the RGC function is correlated to RNFL thickness. ${ }^{12}$

With these advances, ophthalmologists have the chance to evaluate the impact of heavy cigarettes smoking on the retinal nerve fiber layer and ganglion cell layer in more detail. The purpose of this study was to assess the basic morphological and functional changes in RNFL and GCC of heavy smokers in comparison to non-smokers.

\section{Materials and Methods}

\section{Patients}

This study was conducted in the Ophthalmology Department of Benha University Hospitals in the period between
January 2018 and February 2019 after the required ethical approval from the local research ethical committee of Benha Faculty of Medicine. The study followed the basic rules of declaration of Helsinki involving human trials and all participants signed written informed consent.

One hundred and twenty eyes of 60 participants were included in this study. They were divided into two groups according to their smoking status; group (A) 30 heavy smokers (defined as subjects who smoke at least 15 cigarettes per day for 10 years) and group (B) 30 age and gender-matched healthy non-smoker participants.

The inclusion criteria were patients of both gender, age ranged between 29 and 45 years, best corrected visual acuity of 20/20 or better with spherical refraction ranged from +1.0 to -1.0 dioptre and intraocular pressure less than $21 \mathrm{mmHHg}$. Exclusion criteria were any evidence of systemic disease that was diagnosed upon history taking, general physical examination and laboratory investigations such as; diabetes mellitus, hypertension, multiple sclerosis and Alzheimer's disease. Subjects with history of glaucoma, eye trauma, Lasik surgery, retinal surgery, previous retinal diseases, and alcohol or drug intake of preparation that could affect the measurements especially systemic vasoactive substances were also excluded.

\section{Ophthalmological Examination}

Full ophthalmological examination were performed to all subjects including slit-lamp examination, intraocular pressure measurement (IOP) by Goldmann applanation tonometry, refraction, best-corrected visual acuity (BCVA) and fundus examination. The central corneal thickness (CCT), and axial length (AXL) were measured by the LenStar LS900.

SD-OCT (Topcon 3D OCT model 2000 FA version.8.30) was used to measure the peripapillary RNFL and GCC thickness from the macular map scan which calculated automatically through the device's software.

PERG and PhNR were recorded using the RETI-port /scan 21 (Roland Consult, Brandenburg, Germany). The PERG test was performed without Pupils dilation to improve the quality of the retinal image and under photopic condition. Stimulation of both eyes at the same time was used with patient refraction/correction for $100 \mathrm{~cm}$ viewing distance.

PERG stimulation parameters included the following: large and small black-and-white backward-moving checkerboard stimulus $\left(>15^{\circ}\right.$ field of view), $>80 \%$ contrast, mean luminance $50(\mathrm{~cd} / \mathrm{m} 2)$, with a check size equals to $1^{\circ} 2^{\prime}$; and 2 reversals/s.

The ground gold disk electrode was placed over the forehead, while the HK-loop electrode was applied into 
the lower fornix after usage of local anesthesia eye drops and the surface reference electrodes were fixed on the ipsilateral outer canthus skin of each eye. The PERG test was performed following the ISCEV guidelines. ${ }^{13}$

The PhNR examination was performed following the strict ISCEV Standards for the photopic ERG; including pupil dilation and 10 minutes of light adaptation. Ganzfeld settings were: Background blue $25 \mathrm{cds} / \mathrm{m} 2(455 \mathrm{~nm})$, red light flash stimulus $0.4 \mathrm{cds} / \mathrm{m} 2(625 \mathrm{~nm})$, with Inter-flash interval: $1 \mathrm{~s}$.

The PhNR amplitude was identified as the difference between the baseline and the trough of the negative wave following the b-wave (Figure 1). ${ }^{11}$ The implicit time was identified as the time interval from onset of the stimulus and the peak of the negative wave.

\section{Statistical Analysis}

Statistical analysis of the data was performed using the SPSS software version 20. Quantitative information was presented in terms of mean $\pm \mathrm{SD}$, while descriptive data were tested using chi-square test. Independent sample $t$-test and Mann-Whitney $U$-test were utilized accordingly, whenever applicable, for performing inter-group comparisons. Pearson's correlation analysis and Regression analyses assessed various factors that could affect the RNFL and GCC thickness. Comparisons were considered significant when $(\mathrm{p}<0.05)$ and highly significant when $(\mathrm{p}<0.001)$.

\section{Results}

A total of 120 eyes of 60 participants were included in this study, 60 eyes of 30 heavy smokers as the study group (A) and 60 eyes of 30 non-smokers as the control group (B).

\section{PhNR (GF)}

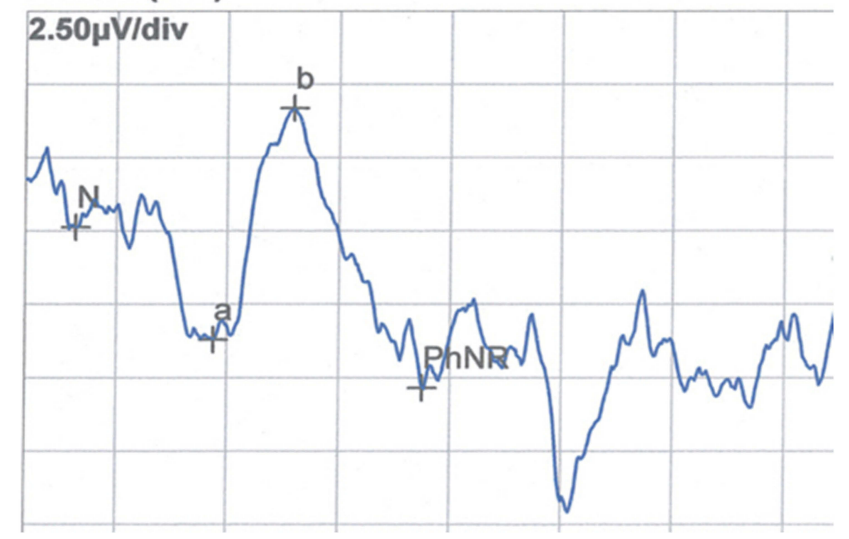

Figure I The PhNR amplitude calculation.

\section{Demographics}

Group A consisted of 22 males (73.3\%) and 8 females (26.7\%) with age ranging from 29 to 44 years, while the control group consisted of 20 males $(66.7 \%)$ and 10 females $(33.3 \%)$ with same age range.

No statistically significant differences regarding age, gender, visual acuity (VA), BCVA, refraction, IOP, AXL and CCT were found between the two groups (Table 1). Group (A) smoked an average of $(36.0 \pm 16.95)$ cigarettes daily with range between 15 and 60 cigarettes. The duration of smoking ranged between 10 and 31 years with mean of $(18.0 \pm 6.60)$ years (Table 2).

The mean RNFL values showed a statistically significant differences between the study and control groups $(p<0.001)$. Furthermore, superior and inferior quadrants of RNFL were significantly thinner in the study group ( $p<0.001$ and $p<0.001$ ) respectively, but no significant differences were found in temporal or nasal quadrants ( $p=0.07$ and $p=0.37$ and) respectively (Table 3 ). Also, total GCC values were significantly thinner in the study (smokers) group in comparison to control group ( $\mathrm{p}<0.001)$ (Table 3) (Figure 2). The reduction of GCC thickness was more in males $(87.0 \pm 6.84 \mu \mathrm{m})$ than females $(92.25 \pm 3.96$ $\mu \mathrm{m})(\mathrm{p}=0.005)$.

There was no significant difference of PERG-P50 amplitude $(p=0.49)$ or latency $(p=0.71)$. However, PERG-N95 amplitude and latency showed significant differences between smokers and non-smokers $(p<0.001)$ (Table 4). There were significant differences of phNR amplitude and latency between the two groups $(\mathrm{p}<$ 0.001) (Table 4).

Significant negative correlation was found between superior, inferior RNFL \& GCC thicknesses with PERGN95 and PhNR latency $(p<0.001)$ (Table 5). On the other hand, there was a significant positive correlation between them with PERG-N95 and PhNR amplitude $(p<0.001)$. Multiple regression analyses demonstrated that the PhNR, PERG amplitude and latency are the most influencing variables on RNFL and GCC thicknesses (Tables 6 and 7).

\section{Discussion}

Smoking has been known to increase the risk for several serious ocular diseases, such as dry eye, glaucoma, ARMD, Graves ophthalmopathy and cataract. ${ }^{14,15}$ Smoking causes high oxidative stress with release of the free radicals that produced by these oxidizing agents which lead to cell damage and death by apoptosis. ${ }^{16}$ 
Table I Demographics and Clinical Findings of the Whole Study Population as Well as Comparison Between the Two Groups

\begin{tabular}{|l|l|l|l|}
\hline & $\begin{array}{l}\text { Group (A) } \\
\text { Smokers } \\
\text { Mean } \pm \text { SD }\end{array}$ & $\begin{array}{l}\text { Group (B) } \\
\text { Control } \\
\text { Mean } \pm \text { SD }\end{array}$ & P value \\
\hline $\begin{array}{l}\text { Gender n (\%) } \\
\text { Male }\end{array}$ & $\begin{array}{l}22(73.3 \%) \\
\text { Female }\end{array}$ & $\begin{array}{l}20(66.7 \%) \\
10(33.3 \%)\end{array}$ & 0.57 \\
\hline Age & $36.67 \pm 4.13$ & $36.0 \pm 4.76$ & 0.56 \\
V/A (logMAR) & $0.053 \pm 0.05$ & $0.03 \pm 0.046$ & 0.01 \\
BCVA(logMAR) & $0.00 \pm 0.00$ & $0.00 \pm 0.00$ & \\
SE (dioptre) & $-0.07 \pm 0.63$ & $-0.03 \pm 0.49$ & 0.71 \\
AXL (mm) & $22.54 \pm 0.86$ & $22.41 \pm 0.67$ & 0.37 \\
CCT (mm) & $517.5 \pm 28.73$ & $518.4 \pm 28.81$ & 0.86 \\
IOP (mmHg) & $14.47 \pm 1.87$ & $14.2 \pm 1.77$ & 0.43 \\
\hline
\end{tabular}

Abbreviations: $\mathrm{VA}=$ visual acuity; $\mathrm{BCVA}=$ best corrected visual acuity; $\mathrm{SE}=$ spherical equivalent; $A X L=$ axial length; $C C T=$ central corneal thickness; $I O P=$ intra ocular pressure.

Table 2 Description of Smoking Status of Study Group

\begin{tabular}{|l|l|l|}
\hline & Mean \pm SD & Range \\
\hline Duration of smoking/year & $18.0 \pm 6.60$ & $10-31$ \\
No of cig/day & $36.0 \pm 16.95$ & $15-60$ \\
\hline
\end{tabular}

Table 3 Comparison of the RNFL and GCC Thickness Between Smokers and Non- Smokers Participants

\begin{tabular}{|c|c|c|c|}
\hline & $\begin{array}{l}\text { Group (A) } \\
\text { Smokers } \\
\text { Mean } \pm \text { SD }\end{array}$ & $\begin{array}{l}\text { Group (B) } \\
\text { Control } \\
\text { Mean } \pm \text { SD }\end{array}$ & $P$ value \\
\hline \multicolumn{4}{|c|}{ RNFL Thickness } \\
\hline $\begin{array}{l}\text { Total } \\
\text { Inferior } \\
\text { Nasal } \\
\text { Superior } \\
\text { Temporal }\end{array}$ & $\begin{array}{l}97.87 \pm 5.88 \\
107.37 \pm 12.58 \\
89.3 \pm 5.77 \\
107.5 \pm 14.47 \\
78.3 \pm 5.4\end{array}$ & $\begin{array}{l}106.43 \pm 6.59 \\
\mid 40.07 \pm 12.01 \\
90.37 \pm 7.01 \\
140.0 \pm 11.09 \\
80.23 \pm 6.14\end{array}$ & $\begin{array}{l}<0.00 I^{* *} \\
<0.00 I^{* *} \\
0.37 \\
<0.00 I^{* *} \\
0.07\end{array}$ \\
\hline \multicolumn{4}{|c|}{ GCC Thickness } \\
\hline $\begin{array}{l}\text { Inferior } \\
\text { Superior } \\
\text { Total }\end{array}$ & $\begin{array}{l}87.73 \pm 8.53 \\
88.77 \pm 7.54 \\
88.4 \pm 6.6\end{array}$ & $\begin{array}{l}95.77 \pm 6.18 \\
94.87 \pm 6.28 \\
94.83 \pm 5.25\end{array}$ & $\begin{array}{l}<0.001^{* *} \\
<0.001^{* *} \\
<0.001^{* *}\end{array}$ \\
\hline
\end{tabular}

Note: **P value is highly significant

Abbreviations: $\mathrm{RNFL}=$ retinal nerve fiber layer; $\mathrm{GCC}=$ ganglion cell complex.

Hepsen and Evereklioglu ${ }^{6}$ demonstrated diminished retinal sensitivity in the visual fields of chronic heavy smokers. Tamaki et $\mathrm{al}^{17}$ reported that heavy cigarette smoking reduce the blood stream tissue velocity and reduce the peripheral vessel dimensions in the choroid and optic nerve head. These findings suggest that chronic smoking might influence the inner retinal layer and retinal ganglion cells.
This study was conducted to assess harmful effects of chronic heavy smoking on RNFL and GCC using multiple imaging modalities. We found that the average RNFL thickness was significantly thinner in heavy smokers than the control group. Sub-analysis showed that the significantly affected quadrants were the superior and inferior, while no significant differences were found in temporal or nasal quadrants between the two groups. These variations in the quadrants could be explained by the less structural support of axons in superior and inferior optic disc poles due to larger lamina cribrosa fenestrations in theses quadrants in comparison to nasal and temporal poles resulting in greater damage to ganglion cell axons in these areas.

These findings concur with the published data by Dervişoğulları et al, ${ }^{18}$ they demonstrated that the average RNFL was significantly thinner in smokers compared with non-smokers. Also, measurements of superior and inferior quadrants were significantly reduced in smoker cases, with no significant changes in temporal or nasal quadrants. Demirci et al stated that cigarette smoking may cause significant reduction of RNFL thickness in migraine patients. ${ }^{19}$

Our results showed that GCC measurements of chronic smokers were much lower than that of non-smokers. This was in accordance with the outcomes reported by Moschos et $\mathrm{al}^{20}$ who demonstrated thinner GCC thickness in smokers. We also found that GCC thickness was more reduced in males than females $(p=0.005)$. This may be due the higher rates of smoking in males than females. ${ }^{21}$ Further research are required to evaluate gender related differences regarding the effects of heavy smoking on ganglion cell layer.

Although El-Shazly et $\mathrm{al}^{22}$ concluded that total RNFL and GCC were not significantly influenced when they compared active and passive smokers, the sub-analysis of the quadrants showed that superior and inferior quadrants of RNFL were thinner in the active smokers than passive smokers, with no change in temporal or nasal quadrants. These findings were fairly similar to our results.

The reduction of the RNFL and GCC thickness could be explained by either direct neurotoxic impact on the optic nerve or the decreased blood stream because of the vasoconstrictive impact of nicotine. ${ }^{23}$

In the present study, PERG-P50 amplitude and latency did not show significant differences between both groups, while PERG-N95 demonstrated statistically significant 


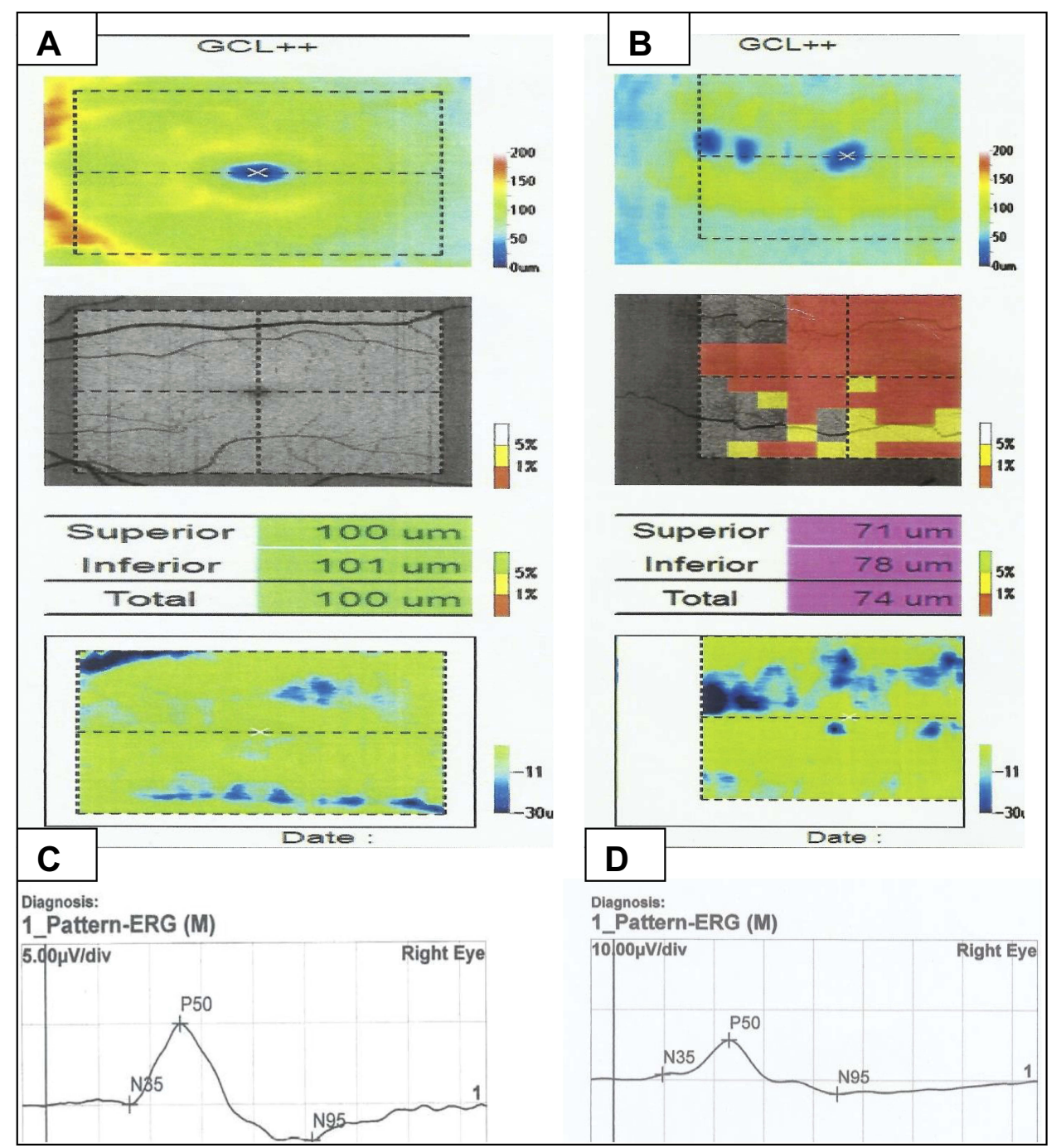

Figure 2 (A) Optical coherence tomography (OCT) of normal control:normal GCC thickness (B) OCT of chronic heavy smoker: there is reduction of GCC thickness (C) PERG of normal control: with normal amplitude and latency (D) PERG of chronic heavy smoker: with decreased amplitude and delay in latency.

Table 4 Comparison of PERG and PhNR Parameters Between Smokers and Non-Smoker Participants

\begin{tabular}{|c|c|c|c|}
\hline & $\begin{array}{l}\text { Group (A) } \\
\text { Smokers } \\
\text { Mean } \pm \text { SD }\end{array}$ & $\begin{array}{l}\text { Group (B) } \\
\text { Control } \\
\text { Mean } \pm \text { SD }\end{array}$ & $P$ value \\
\hline \multicolumn{4}{|l|}{ Pattern ERG(PERG) } \\
\hline $\begin{array}{l}\text { P50 latency }(\mathrm{ms}) \\
\text { N95 latency }(\mathrm{ms}) \\
\text { P50 amplitude }(\mu \mathrm{V}) \\
\text { N95 amplitude }(\mu \mathrm{V})\end{array}$ & $\begin{array}{l}50.56 \pm 1.61 \\
107.39 \pm 6.22 \\
4.10 \pm 0.83 \\
2.96 \pm 1.09\end{array}$ & $\begin{array}{l}50.45 \pm 1.53 \\
94.8 \pm 3.21 \\
4.2 \pm 0.69 \\
5.74 \pm 0.92\end{array}$ & $\begin{array}{l}0.7 \mathrm{I} \\
<0.00 I^{* *} \\
0.49 \\
<0.00 \text { I** }\end{array}$ \\
\hline \multicolumn{4}{|c|}{ Photopic Negative Response(PhNR) } \\
\hline $\begin{array}{l}\mathrm{PhNR} \text { amplitude }(\mu \mathrm{V}) \\
\text { phNR implicit time(ms) }\end{array}$ & $\begin{array}{l}|2.43 \pm 1.7| \\
59.4 \mid \pm 2.02\end{array}$ & $\begin{array}{l}|9.22 \pm| .4 \mid \\
52.02 \pm 2.39\end{array}$ & $\begin{array}{l}<0.00 I^{* *} \\
<0.00 I^{* *}\end{array}$ \\
\hline
\end{tabular}

Note: **P value is highly significant.

Abbreviations: PERG = pattern electroretinogram; phNR = photopic negative response. differences between the smokers and control groups. These results are comparable to studies by El-Shazly et al, ${ }^{22}$ Gündogân et $\mathrm{al}^{24}$ and Holder ${ }^{25}$ which reported that smoking affects PERG amplitude and latency significantly in heavy smokers compared with non-smokers.

We also found significant reduction of phNR amplitude and prolonged latency in heavy smokers compared with control group.PERG-N95 and phNR are objective tests for ganglion cell functions. ${ }^{26,27}$ The phNR arises from the electrical activity of RGC and their axons, so it is a useful diagnostic tool for diseases affecting the inner retina and optic nerve such as glaucoma, ${ }^{28}$ however the amount of research involving the phNR is insufficient.

In heavy smokers group we found a significant positive correlation between RNFL and GCC thickness with 
Table 5 Correlation Between RNFL, GCC Thickness with Other Variables

\begin{tabular}{|c|c|c|c|c|c|c|c|c|c|c|c|c|}
\hline \multirow{2}{*}{$\begin{array}{l}\text { RNFL Thickness } \\
\text { Smokers (60) }\end{array}$} & \multicolumn{2}{|c|}{ Superior } & \multicolumn{2}{|c|}{ Inferior } & \multicolumn{2}{|l|}{ Total } & \multicolumn{2}{|c|}{ Inferior GCC } & \multicolumn{2}{|c|}{ Superior GCC } & \multicolumn{2}{|c|}{ Total GCC } \\
\hline & $\mathbf{R}$ & $P$ & $r$ & $P$ & $\mathrm{R}$ & $P$ & $\mathrm{R}$ & $P$ & r & $P$ & $r$ & $P$ \\
\hline PERG/P50 latency & 0.43 & $0.001 * *$ & 0.06 & 0.66 & 0.07 & 0.59 & 0.19 & 0.16 & 0.22 & 0.09 & 0.28 & 0.03 \\
\hline PERG/N95 latency & -0.59 & $<0.001^{* *}$ & -0.64 & $<0.001 * *$ & -0.74 & $<0.001 * *$ & -0.46 & $<0.001^{* *}$ & -0.52 & $<0.001 * *$ & 0.02 & 0.89 \\
\hline PERG/p50 amplitude & 0.39 & $0.002 * *$ & 0.44 & $<0.00 I^{* *}$ & 0.63 & $<0.001 * *$ & 0.48 & $<0.001^{* *}$ & 0.50 & $<0.001 * *$ & 0.02 & 0.90 \\
\hline PERG.N95 amplitude & 0.47 & $<0.001^{* *}$ & 0.59 & $<0.001 * *$ & 0.53 & $<0.001 * *$ & 0.49 & $<0.001^{* *}$ & 0.59 & $<0.001 * *$ & 0.22 & 0.099 \\
\hline $\mathrm{AXL}(\mathrm{mm})$ & -0.17 & 0.19 & -0.28 & 0.03 & -0.26 & 0.045 & -0.023 & 0.86 & -0.04 & 0.76 & -0.03 & 0.82 \\
\hline CCT (mm) & -0.10 & 0.44 & 0.12 & 0.35 & 0.10 & 0.44 & 0.13 & 0.33 & 0.05 & 0.68 & 0.13 & 0.34 \\
\hline PhNR amplitude & 0.69 & $<0.001^{* *}$ & 0.63 & $<0.001^{* *}$ & 0.67 & $<0.00 I^{* *}$ & 0.36 & $0.005^{* *}$ & 0.54 & $<0.00 I^{* *}$ & -0.09 & 0.49 \\
\hline phNR implicit time & -0.58 & $<0.001^{* *}$ & $-0.6 \mathrm{I}$ & $<0.00 I^{* *}$ & -0.63 & $<0.001 * *$ & -0.39 & $0.002 * *$ & -0.39 & $0.002^{* *}$ & -0.10 & 0.43 \\
\hline
\end{tabular}

Note: **P value is highly significant.

Abbreviations: $\mathrm{RNFL}=$ retinal nerve fiber layer; $\mathrm{GCC}=$ ganglion cell complex; $\mathrm{PERG}=$ pattern electroretinogram; $\mathrm{phNR}=$ photopic negative response; $\mathrm{AXL}=$ axial length; $\mathrm{CCT}=$ central corneal thickness.

Table 6 Stepwise Linear Regression of Superior \& Inferior RNFL Thickness with Other Variables

\begin{tabular}{|c|c|c|c|c|c|c|}
\hline \multirow[t]{2}{*}{ The Independent } & & \multirow{2}{*}{$\begin{array}{l}\text { Unstandardized } \\
\text { Coefficients (B) }\end{array}$} & \multirow[t]{2}{*}{$\mathbf{T}$} & \multirow[t]{2}{*}{ Sig. } & \multicolumn{2}{|c|}{$95.0 \%$ Confidence Interval for B } \\
\hline & & & & & Lower Bound & Upper Bound \\
\hline \multirow[t]{10}{*}{ Superior RNFL Thickness } & PERG/P 50 latency & 3.584 & 4.550 & 0.000 & 2.004 & 5.163 \\
\hline & PERG/N 95 latency & $-0.446-$ & $-1.234-$ & 0.223 & -1.170 & 0.278 \\
\hline & PERG/p50 amplitude & $-3.702-$ & $-1.713-$ & 0.093 & $-8.036-$ & 0.633 \\
\hline & PERG/N95 amplitude & 2.631 & 1.363 & 0.179 & -1.240 & 6.501 \\
\hline & phNR amplitude & 4.691 & 2.990 & 0.004 & 1.544 & 7.838 \\
\hline & phNR implicit time & 0.460 & 0.354 & 0.724 & $-2.144-$ & 3.064 \\
\hline & $\mathrm{F}$ & \multirow{4}{*}{\multicolumn{5}{|c|}{$\begin{array}{l}|5.9| \\
<0.00 \mid * * \\
0.64 \\
0.60\end{array}$}} \\
\hline & $P$ value & & & & & \\
\hline & & & & & & \\
\hline & Adjusted $\mathrm{R}^{2}$ & & & & & \\
\hline \multirow[t]{10}{*}{ Inferior RNFL Thickness } & N 95 latency & -1.29 & 6.32 & $0.001 * *$ & -1.7 & 0.88 \\
\hline & PERG/p50 amplitude & 0.006 & 0.046 & 0.96 & $-4.754-$ & 4.083 \\
\hline & PERG/N95 amplitude & 0.286 & 2.14 & $0.036 *$ & $-1.895-$ & 5.742 \\
\hline & $\mathrm{AXL}(\mathrm{mm})$ & 0.18 & 1.81 & 0.076 & $-5.364-$ & 0.931 \\
\hline & phNR amplitude & 0.349 & 2.27 & $0.027^{*}$ & -2.639 & 4.287 \\
\hline & phNR implicit time & -0.334 & 2.55 & $0.013^{*}$ & $-3.813-$ & 1.660 \\
\hline & $\mathrm{F}$ & \multicolumn{5}{|l|}{39.95} \\
\hline & $P$ value & \multicolumn{5}{|l|}{$<0.001 * *$} \\
\hline & $R^{2}$ & \multicolumn{5}{|l|}{0.41} \\
\hline & Adjusted $\mathrm{R}^{2}$ & \multicolumn{5}{|l|}{0.40} \\
\hline
\end{tabular}

Notes: *P value is significant, **P value is highly significant.

Abbreviations: $R N F L=$ retinal nerve fiber layer; PERG = pattern electroretinogram; $p h N R=$ photopic negative response; $A X L=$ axial length.

PERG-N95 and PhNR amplitude, while the RNFL and GCC thickness were negatively correlated with PERGN95 and PhNR latency. These outcomes may indicate that smoking affects mainly the RNFL and optic nerve.

One limitation of this study was the relatively small sample size. Further examinations and studies involving bigger numbers of samples are needed to measure the influence of heavy smoking on different retinal parameters.

In conclusion, RNFL and GCC thickness decrease in chronic heavy smokers, the PhNR and PERG-N95 amplitudes were diminished and the implicit times were delayed in comparison to non-smokers. PhNR and PERG reflect both dysfunction and loss of ganglion cells and their axons. 
Table 7 Stepwise Linear Regression of Superior \& Inferior GCC Thickness with Other Variables

\begin{tabular}{|c|c|c|c|c|c|c|}
\hline \multirow[t]{2}{*}{ Inferior GCC Thickness } & $\begin{array}{l}\text { PERG/N } 95 \text { latency } \\
\text { PERG/p50 amplitude } \\
\text { PERG/N95 amplitude } \\
\text { phNR amplitude } \\
\text { phNR implicit time }\end{array}$ & $\begin{array}{l}-0.092- \\
4.387 \\
2.500 \\
-1.564- \\
-0.777-\end{array}$ & $\begin{array}{l}-0.324- \\
2.587 \\
1.714 \\
-1.280- \\
-0.762-\end{array}$ & $\begin{array}{l}0.747 \\
0.012 \\
0.092 \\
0.206 \\
0.450\end{array}$ & $\begin{array}{l}-0.660- \\
0.987 \\
-0.425- \\
-4.014- \\
-2.821-\end{array}$ & $\begin{array}{l}0.477 \\
7.787 \\
5.424 \\
0.886 \\
1.268\end{array}$ \\
\hline & $\begin{array}{l}F \\
P \text { value } \\
R^{2} \\
\text { Adjusted } R^{2}\end{array}$ & \multicolumn{5}{|l|}{$\begin{array}{l}5.91 \\
<0.001 * * \\
0.35 \\
0.29\end{array}$} \\
\hline \multirow[t]{2}{*}{ Superior GCC Thickness } & $\begin{array}{l}\text { PERG/N } 95 \text { latency } \\
\text { PERG/p50 amplitude } \\
\text { PERG/N95 amplitude } \\
\text { phNR amplitude } \\
\text { phNR implicit time }\end{array}$ & $\begin{array}{l}0.096 \\
1.317 \\
4.845 \\
2.517 \\
2.281\end{array}$ & $\begin{array}{l}0.440 \\
1.012 \\
4.331 \\
2.685 \\
2.917\end{array}$ & $\begin{array}{l}0.662 \\
0.316 \\
0.000 \\
0.010 \\
0.005\end{array}$ & $\begin{array}{l}-0.340- \\
-1.291- \\
2.602 \\
0.638 \\
0.713\end{array}$ & $\begin{array}{l}0.532 \\
3.924 \\
7.088 \\
4.396 \\
3.849\end{array}$ \\
\hline & $\begin{array}{l}F \\
P \text { value } \\
R^{2} \\
\text { Adjusted } R^{2}\end{array}$ & \multicolumn{5}{|l|}{$\begin{array}{l}11.38 \\
<0.001 * * \\
0.51 \\
0.47\end{array}$} \\
\hline
\end{tabular}

Note: **P value is highly significant.

Abbreviations: $\mathrm{GCC}$ = ganglion cell complex; PERG = pattern electroretinogram; $\mathrm{phNR}=$ photopic negative response.

\section{Acknowledgments}

The abstract of this paper was presented at the 57th Annual Symposium of the International Society for Clinical Electrophysiology of Vision (ISCEV 2019) Conference at Seoul/south Korea 5-10 Octobre as a poster presentation with interim findings. The poster's abstract was published in "Poster Abstracts" in Journal Documenta Ophthalmologica, Springer.

\section{Disclosure}

The authors report no conflicts of interest in this work.

\section{References}

1. Müezzinler A, Mons U, Gellert C, et al. Smoking and all-cause mortality in older adults: results from the CHANCES consortium. Am J Prev Med. 2015;49(5):e53-e63. doi:10.1016/j.amepre.2015.04.004

2. Solberg Y, Rosner M, Belkin M. The association between cigarette smoking and ocular diseases. Surv Ophthalmol. 1998;42:535-547. doi:10.1016/S0039-6257(98)00002-2

3. Asfar T, Lam BL, Lee DJ. Smoking causes blindness: time for eye care professionals to join the fight against tobacco. Invest Ophthalmol Vis Sci. 2015;56(2):1120-1121. doi:10.1167/iovs.15-16479

4. Kolar P Risk factors for central and branch retinal vein occlusion: a meta-analysis of published clinical data. J Ophthalmol. 2014;2014:5. doi: 10.1155/2014/724780.724780

5. Grzybowski A, Holder GE. Tobacco optic neuropathy(TON) - the historical and present concept of the disease. Acta Ophthalmol (Copenh). 2011;89 (5):495-499. doi:10.1111/j.1755-3768.2009.01853.x

6. Hepsen IF, Evereklioglu C. Defective visual field tests in chronic heavy smokers. Acta Ophthalmol Scand. 2001;79(1):53-56. doi:10.1034/j.1600-0420.2001.079001053.x
7. Mwanza JC, Budenz DL, Godfrey DG, Carter R, Crandall AS. Diagnostic performance of optical coherence tomography ganglion cell inner plexiform layer thickness measurements in early glaucoma. Ophthalmology. 2012;119(6):1151-1158. doi:10.1016/j.ophtha.2011.12.014

8. Akamine T, Nishimura Y, Ito K, Uji Y, Yamamoto T. Effects of haloperidol on $\mathrm{K}(+)$ currents in acutely isolated rat retinal ganglion cells. Invest Ophthalmol Visual Sci. 2002;43(4):1257-1261.

9. Holder GE. Pattern electroretinography(PERG) and an integrated approach to visual pathway diagnosis.progress in retinal and eye research. Prog Retinal Eye Res. 2001;20(4):531-561. doi:10.1016/ s1350-9462(00)00030-6

10. Kim HD, Park JY, Ohn Y-H. Clinical applications of photopic negative response (PhNR) for the treatment of glaucoma and diabetic retinopathy. Korean J Ophthalmol. 2010;24(2):89-95. doi:10.3341/kjo.2010.24.2.89

11. Frishman L, Sustar M, Kremers J. ISCEV extended protocol for the photopic negative response (PhNR) of the full-field electroretinogram. Doc Ophthalmol. 2018;136(3):207-211. doi:10.1007/s10633-018-9638-x

12. Ventura LM, Sorokac N, De Los Santos R, et al. The relationship between retinal ganglion cell function and retinal nerve fiber thickness in early glaucoma. Invest Ophthalmol Vis Sci. 2006;47:3904-3911. doi:10.1167/iovs.06-0161

13. Bach M, Brigell MG, Hawlina M, et al. ISCEV standard for clinical pattern electroretinography (PERG): 2012 update. Doc Ophthalmol. 2013;126(1):1-7. doi:10.1007/s10633-012-9353-y

14. Cheng ACK, Pang CP, Leung ATS, Chua JKH, Fan DSP, Lam DSC. The association between cigarette smoking and ocular diseases. HKMJ. 2000;6:195-2022.

15. Morgan RW, Drance SM. Chronic open-angle glaucoma and ocular hypertension: an epidemiology study. $\mathrm{Br} J$ Ophthalmol. 1975;59:211-2153. doi:10.1136/bjo.59.4.211

16. Bertram KM, Baglole CJ, Phipps RP, Libby RT. Molecular regulation of cigarette smoke induced-oxidative stress in human retinal pigment epithelial cells: implications for age-related macular degeneration. Am J Physiol Cell Physiol. 2009;297:C1200-C1210. doi:10.1152/ ajpcell.00126.2009 
17. Tamaki Y, Araie M, Nagahara M, Tomita K, Matsubara M. The acute effects of cigarettes smoking on human optic nerve head and posterior fundus circulation in light smokers. Eye. 2000;14(Part 1):67-72. doi:10.1038/eye.2000.15

18. Dervişoğulları MS, Totan Y, Tenlik A, Yüce A, Güler E. Effect of smoking on retina nerve fiber layer and ganglion cell-inner plexiform layer complex. Cutan Ocul Toxicol. 2015;34(4):282-285. doi:10.3109/15569527.2014.975240

19. Demirci S, Gunes A, Demirci S, Kutluhan S, Tok L, Tok O. The effect of cigarette smoking on retinal nerve fiber layer thickness in patients with migraine. Cutan Ocul Toxicol. 2015;1-5. doi:10.3109/ 15569527.2014.1003935

20. Moschos MM, Nitoda E, Laios K, Ladas DS, Chatziralli IP. The impact of chronic tobacco smoking on retinal and choroidal thickness in Greek population. Oxid Med Cell Longev. 2016;2016:2905789.

21. Chinwong D, Mookmanee N, Chongpornchai J, Chinwong S. A comparison of gender differences in smoking behaviors, intention to quit, and nicotine dependence among thai university students. $J$ Addict. 2018;37:739-742. Article ID 8081670.

22. El-Shazly AA, Farweez YAT, Elewa LS, Elzankalony YA, Farweez BAT. Effect of active and passive smoking on retinal nerve fibre layer and ganglion cell complex. $J$ Ophthalmol. 2017;10. doi: 10.1155/2017/6354025. Article ID 6354025.
23. Langhans M, Michelson G, Groh MJ. Effect of breathing 100\% oxygen on retinal and optic nerve head capillary blood flow in smokers and non-smokers. Br J Ophthalmol. 1997;181(5):365-369. doi:10.1136/bjo.81.5.365

24. Gundogan FC, Durukan AH, Mumcuoglu T, Sobacı G, Bayraktar MZ. Acute effects of cigarette smoking on pattern electroretinogram. Doc Ophthalmol. 2006;113(2):115-1217. doi:10.1007/s10633-006-9021-1

25. Holder GE. The pattern electroretinogram. In: Heckenlively JR, Arden GB, editors. Principles and Practice of Clinical Electrophysiology of Vision. Cambridge: MIT Press; 2006:341-352.

26. Luo X, Frishman LJ. Retinal pathway origins of the pattern electroretinogram (PERG). Invest Ophthalmol Vis Sci. 2011;52:8571-8584. doi:10.1167/iovs.11-8376

27. Viswanathan S, Frishman LJ, Robson JG, Walters JW. The photopic negative response of the flash electroretinogram in primary open angle glaucoma. Invest Ophthalmol Vis Sci. 2001;42:514-522.

28. Rangaswamy NV, Shirato S, Kaneko M, Digby BI, Robson JG, Frishman LJ. Effects of spectral characteristics of Ganzfeld stimuli on the photopic negative response (PhNR) of the ERG. Invest Ophthalmol Vis Sci. 2007;48:4818-4828. doi:10.1167/iovs.07-0218
Clinical Ophthalmology

\section{Publish your work in this journal}

Clinical Ophthalmology is an international, peer-reviewed journal covering all subspecialties within ophthalmology. Key topics include: Optometry; Visual science; Pharmacology and drug therapy in eye diseases; Basic Sciences; Primary and Secondary eye care; Patient Safety and Quality of Care Improvements. This journal is indexed on PubMed

\section{Dovepress}

Central and CAS, and is the official journal of The Society of Clinical Ophthalmology (SCO). The manuscript management system is completely online and includes a very quick and fair peer-review system, which is all easy to use. Visit http://www.dovepress.com/ testimonials.php to read real quotes from published authors. 